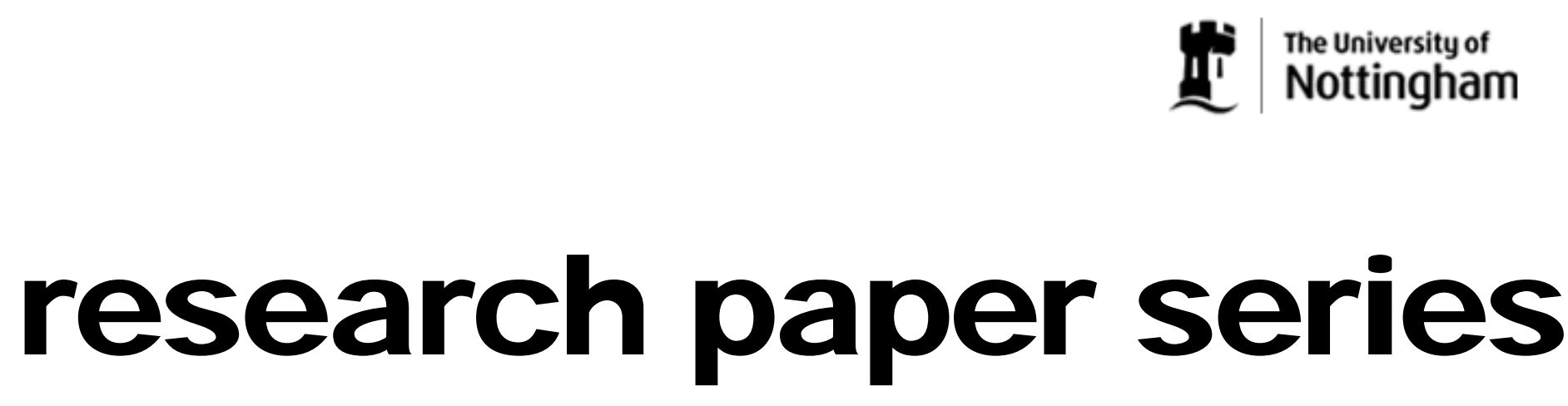

China and the World Economy

Research Paper 2009/12

Finance and Firm Start-up Size: Quantile Regression Evidence from China

By

Jun Du and Sourafel Girma 


\section{The Authors}

Jun Du is a Lecturer at Aston Business School; Sourafel Girma is a GEP Internal Fellow and Professor of Industrial Economics at the University of Nottingham Business School.

\section{Acknowledgements}

Jun Du acknowledges financial support from the project, "Privatisation, foreign investment and firm performance in China”, funded by the ESRC (Award RES-000-22-0729). 


\title{
Finance and Firm Start-up Size: Quantile Regression Evidence from China
}

\author{
by
}

\author{
Jun Du and Sourafel Girma
}

\begin{abstract}
Using a unique dataset which provides information on the financial structure of start-up companies in the Chinese manufacturing industry, this paper documents robust evidence that access to formal financing channels has beneficial effects on firm size, these effects being more marked as we move up the entry size distribution. By contrast we find negative relationships between informal finance and entry size across all size quantiles. Given the well-documented positive correlations between firm size and numerous performance indicators, this paper has therefore uncovered entry size as an additional channel through which financial development promotes growth.
\end{abstract}

JEL Classification: O5 G2

Keywords: China, finance, growth

\section{Outline}

1. Introduction

2. Firms' financing pattern in China

3. Empirical methodology

4. Database description

5. Empirical findings

6. Conclusions 


\section{Non-Technical Summary}

New firms play a significant role in industry dynamics by creating a large number of jobs, introducing innovative production techniques and providing competitive stimulus to market incumbents. The literature shows that while there is a particularly robust positive correlation between start-up size and firm performance, financial constraints hamper firms from reaching their optimal size in the earlier stage of their life cycle. The purpose of this paper is to investigate the role of various financing channels - formal channels such as bank loans, foreign finance, state finance, and informal financing sources (i.e. self raised finance) - in determining the size of start-up companies in China. We draw on a large and recent dataset that uniquely provides information on the financial structure of start-ups, and employ quantile regression technique to trace out the differential effects of finance across the entire start-up size distribution. To our knowledge this is the first study of its kind.

The paper documents robust evidence that access to formal financing channels has beneficial effects on firm size, these effects being more marked as we move up the entry size distribution. By contrast, we find negative relationships between informal finance and entry size across all size quantiles. Given the welldocumented positive correlations between firm size and numerous performance indicators (e.g. productivity, exporting and survival), this paper has therefore uncovered entry size as an additional channel through which financial development promotes growth. The finding has relevance to the vibrant literature on finance and growth, especially to the strand of the literature that seeks to document the distributional effects of financial development. This work has also an important policy implication. Given the relationship between firm size and performance, the extent to which Chinese start-up companies will create longer lasting jobs as well as significantly contribute to aggregate productivity growth is directly related to their access to the state-dominated banking system. In this sense, our paper has highlighted the potential benefits of more tightly coordinating the on-going reforms of the Chinese financial system with existing industrial development strategies 


\section{Introduction}

It is now well-understood in the economic literature that new firms play a significant role in industry dynamics by creating a large number of jobs, introducing innovative production techniques and providing competitive stimulus to market incumbents (e.g. Geroski, 1991 and Caves, 1998). The literature also shows that while there is a particularly robust positive correlation between start-up size and firm performance (e.g. Mata and Portugal 1995), financial constraints hamper firms from reaching their optimal size in the earlier stage of their life cycle (Cabral and Mata, 2003).

The purpose of this paper is to investigate the role of various financing channels formal channels such as bank loans, foreign finance, state finance, and informal financing sources (i.e. self raised finance) - in determining the size of start-up companies in China. We draw on a large and recent dataset that uniquely provides information on the financial structure of start-ups, and employ quantile regression technique (Koenker and Bassett, 1978) to trace out the differential effects of finance across the entire start-up size distribution. To our knowledge this is the first study of its kind.

This work fits into the recent debate in the growth and finance literature on the relative contribution of formal and informal financing channels to China's phenomenal growth experience over recent years (e.g. Allen et al., 2005). It is also relevant to the wider debate on the role of informal financial arrangements in a country's economic growth (Stiglitz, 1990 and Arott and Stiglitz 1990). Moreover, our study contributes to the body of work on the distributional effects of financial development which suggests that firms at the lower end of the size distribution benefits disproportionately from financial development (Beck et al 2005), but also that bigger firms are more likely to depend on long-term financing and larger loans for their development (Beck, et al 2007). 
A survey conducted in 2002 shows that self-raised finance was the major financing source of Chinese start-up firms ${ }^{1}$ (Garcia-Fontes 2005). According the World Bank Investment Climate Survey for China, not only start-ups but also more generally small and medium enterprises (SMEs) face important credit constraints even compared to other Asian countries (Dollar et al 2003). In spite of the financial constraints, SMEs in China account for $40 \%$ of the total industrial outputs and nearly $30 \%$ of total profit in $2005^{2}$. It is therefore one of the objectives of this paper to inform the policy debate on the role financial policy should have in fostering industry dynamics through the entry of strong and competitive firms.

The rest of the paper is organized as follows. Section 2 sets the scene by giving an overview of firms' financing pattern in China. Section 3 explains the econometric methodology and Section 4 discusses the dataset used in the analysis. The main findings of the paper are presented in Section 5. Section 6 concludes.

\section{Firms' financing pattern in China}

China's formal financial system is dominated by four large state-owned commercial banks that enjoy around $70 \%$ market share in terms of both savings and loans during 1995-2002 (Du, 2006). These banks used to carry policy-related functions which partially explain the soft-budget constraint phenomenon (Lin et al, 1998). China's capital market

\footnotetext{
${ }^{1}$ The survey was conducted by the Project Group of Research in Chinese Private Enterprises organized by China industrial and Commercial Union and Research Commission of Chinese Private Business in 2002. The start-ups were found to be financed mainly by self-accumulated money, private borrowings and Rural Credit Corporations.

${ }^{2}$ Data Source: China Statistical Year Book 2006. This is according to the small firm definition of the National Statistical Bureau of Statistics. For manufacturing industrial firms, small firms are below 300 employees, 3,000,000 RMByuan total sales, and 4,000,000 RMByuan total assets; big firms are above 2,000 employees, 30,000,000 RMByuan total sales, and 40,000,000 RMByuan total assets; medium firms are between the two sets of figures.
} 
is rather small by international standard ${ }^{3}$ (Allen et al., 2005), the two stock exchange markets were established in the early 1990s, and by 2004 only 1,337 companies were listed in the two markets. The stock market is therefore not a relevant channel of finance for the majority of domestic firms.

The majority of Chinese firms are typically financed from a mixture of bank loans (debt) and equity finance from state budget, self-raised financing channels and foreign investment. Domestic bank loans are borrowings from domestic banks and nonbank financial institutions. According to our calculations, the role of bank loans in financing firms has declined over time. In 1998, 50\% of firms had bank loans and this figure has decreased to $25 \%$ in 2005 . During the same period, the average share of bank loans in total capital has dropped from $22 \%$ to $9 \%$, suggesting increased availability of alternative financing sources.

State budget appropriations refer to the appropriations in the budget of the central and local governments earmarked for capital investment. This type of financial allocation has diminished gradually. For example, the average proportion of firms getting state budgets has dropped from 33\% in 1998 to $6 \%$ in 2005; and the average percentage of state budget in firms' capital has declined from $21 \%$ to $3 \%$ over the same period (Du and Girma, 2008).

The third and important source of finance for many firms is self-raised finance. This includes firms' finance from capital markets, bonds issued by individual enterprises, individual borrowing and funds channelled through local governments or collectives. This is similar to what is referred to as informal finance in Maksimovic et al (2008).

3 As Allen et al (2005) show, China's total value traded over GDP is only 0.11 while the LLSV-sample average (La Porta, Lopez-de-Silanes, Shleifer, Vishny, 1998) is 0.27; its market capitalization over GDP is 0.32 while the sample average is 0.47 . 
Informal financial sectors are comprised of savers, lenders and borrowers that can be individuals, firms or associations that act as financial intermediaries but not regulated by authorities. One of the striking characteristics of the informal financial sector is the importance of personal relationships (Germidies, Kessler and Meghir, 1991; Allen et al., 2005).

The fourth source of firm finance is foreign investment and it refers to the finance invested as equity capital by foreign investors and funds borrowed from foreign sources and managed by domestic enterprises. It has been argued that the large amount of foreign direct investment in China is an indicator of indigenous private sector firms' financial constraints (Huang, 2003).

Du and Girma $(2007,2008)$ document the details of the financial sectors in China and the financing channels of the Chinese manufacturing firms, in which they report that during 1998-2005, finance from state budgets, domestic bank loans, self-raised finance and foreign investment accounted for $9.59 \%, 14.28 \%, 62.35 \%$, and $13.79 \%$ of firms' total finance respectively.

\section{Empirical methodology}

To assess the impact of financing sources on firms' start-up size, the following reduced form equation is specified:

$$
\text { Size }_{i t}=\beta^{\prime} F I N_{i t}+\gamma^{\prime} I N D_{j t-1}+\delta^{\prime} D_{i t}+\varepsilon_{i t}
$$

where SIZE is entry size for start-up firm $i$ at time $t$ measured by log of employment, FIN is a vector of financing source variables: state finance, domestic banks loans, selfraised finance and foreign finance. $D$ is a set of time dummies and industry dummies and $\varepsilon$ is the error term. The vector IND consists of a set of lagged three-digit industry 
(denoted by industry j) characteristics that are found to determine start-up size in the literature (e.g. Geroski, 1995; Mata and Machado, 1996 and Görg and Strobl 2001). These industry characteristics include minimum efficient scale (MES), turbulence (TURB), the growth (INDG), foreign penetration (FDI) and concentration (HERF). MES is measured as the log of median industry employment size as suggested by Sutton (1991). It seems reasonable to assume that, the higher MES in an industry, the larger, on average, will be new start-ups in order to be able to compete effectively in the market. We would, hence, expect a positive relationship between the size of entrants and the MES. TURB is measured as the sum of employment shares in firms that have entered or exited the industry from $t$-1 to $t$ as suggested by Beesley and Hamilton (1984). Large scale simultaneous entry and exit in an industry can be taken as evidence of low sunk costs. Assuming that entrants are risk averse, one may expect that, the lower are sunk costs, the higher will be the start-up size of new entrants as the losses associated with a possible failure are lower. INDG is measured by industry sales growth rates. In a fast growing industry, the probability of a plant surviving is higher than in a slow growing industry as incumbents may be less likely to retaliate in a fast growing market. This implies that entrants may choose to enter at a larger size in fast growing markets, due to the higher probability of survival. $H E R F$ is measured as the Herfindahl index, calculated in terms of market shares, and existing evidence shows that positive relationship exists between industry concentration and entry size (Holmes and Stevens, 2002). Finally, FDI is defined as the proportion of industry sales accounted by foreign multinational companies. Görg and Strobl (2001) provide evidence that a high presence of multinationals in an industry leads to a reduction in plant start-up size, due to competition effects. 
A natural way of analysing the differential effects of finance across the firm size distribution is by deploying quantile regression technique (Koenker and Bassett, 1978). Denoting the vector of regressors in Equation (1) by $Z$, the quantile regression model can be written as

$$
\operatorname{SIZE}_{i t}=Z_{i t}^{\prime} \beta_{\theta}+\varepsilon_{\theta i t}, \text { Quant }_{\theta}\left(\operatorname{SIZE}_{i t} \mid Z_{i t}\right)=Z_{i t}^{\prime} \beta_{\theta}
$$

where Quant $_{\theta}\left(\Delta S I Z E_{i t} \mid Z_{i t}\right)$ denotes the conditional quantile of SIZE. The distribution of the error term $\varepsilon_{\theta}$ is left unspecified, so the estimation method is semiparametric. At the $\theta^{\text {th }}$ quantile, $0<\theta<1$, quantile regression solves

$$
\min _{\beta} \frac{1}{N}\left\{\sum_{\text {Size } \geq z^{\prime} \beta} \theta \mid \text { Size }_{i t}-Z_{i t}^{\prime} \beta\left|+\sum_{\text {Size }<z^{\prime} \beta}(1-\theta)\right| \text { Size }_{i t}-Z_{i t}^{\prime} \beta \mid\right\}
$$

where $\mathrm{N}$ is the sample size.

Thus by increasing $\theta$ from 0 to 1 , one can trace the effects of finance on the entire distribution of firm size, conditional on the set of control variables. Thus, quantile regressions allow us to focus attention on specific parts of the SIZE distribution, and identify where in this distribution finance exerts the greatest or the least significant impact.

\section{Database description}

Our econometric analysis draws on the Annual Report of Industrial Enterprise Statistics compiled by the National Statistical Bureau of China (NSB). It is estimated that the firms contained in the data set account for about $85-90 \%$ of total output in most industries. The NSB performs several logic tests to ensure the accuracy of the information in the report and identify illogical data. The data set includes variables such 
as ownership structure, financing sources industry affiliation, establishment year, employment, gross output, value-added.

The dataset used in this paper spans the period 1999 to 2005, and comprises more than 1.3 million firm-year observations. It is worth noting that we used the whole sample to construct industry-level variables (e.g. industry entry and exit rates). However, in view of the objective of this paper, the econometric work is confined to the indigenous start-up companies. Since our empirical model controls for pre-entry (lagged) industry characteristics, we focus on start-up firms between 2000 and 2005. A firm is defined to be a new entrant at time $t$ if its establishment year is given as time $t$ and it is observed in the database for the first time at time $t$. This tight definition helps avoid measurement error problems in the establishment year variable. A nice feature of the database is that it maintains a unique enterprise identifier irrespective of the dynamics of ownership change, so we will be able to distinguish between genuine new entrants and exiting firms operating under a new ownership structure.

We identified 91578 start-ups over the period 2000-2005 that have the necessary information for the econometric estimation. Table 1 gives the frequency distribution of the entrants by year and by technology intensity of their industry (see Appendix A for the definition of technology intensity). Figure 1 shows histograms of start-up size for 2000 and 2005, and Table 2 gives some summary statistics of variables used in the empirical analysis.

\section{Empirical Findings}

Table 3 reports the quantiles regression estimates. Starting with the industry level control variables, it is interesting to observe that generally these variables have the 
expected signs as discussed in Section 3. However, we also observe some interesting heterogeneity across the size distribution. For example, industry level FDI does not exert any effects on the entry size of firms at the top end of the distribution, whereas it has negative ramifications elsewhere in the distribution.

Turning our attention to the impact of the financing channels, we uncover evidence that self-raised finance has deleterious effects on entry size, this negative impact being more pronounced at the upper end of the size distribution. This finding is consistent with the notion that larger firms are more likely to depend on formal financing and larger bank loans for their development. This finding is reinforced by the results of positive relationship between entry size and access to formal financing channels (bank loans, foreign investment and in come cases state budget). As Table 3 and Figure 2 show, the relationship between bank loans and entry size gets stronger as we move up the entry size distribution. To the extent that firm size and performance are correlated, our econometric results suggest that financial development is likely to foster growth through its positive effects on entry size. This is an important finding which has not been previously documented in the finance and growth literature (e.g. Levine, 2005).

The quantile regressions estimates also show that start-ups that enjoy foreign finance and state finance tend to be bigger than otherwise equivalent firms. It is a stylised fact that new entrants are exposed to high risk of exit, especially in the first post-entry years. As Geroski (1995) put it, "the most palpable consequence of entry is exit". Influential theoretical models such as Javanovic (1982) and Pakes and Ericson (1998) predict that firms' decision to expand in size depends on their expectation about their efficiency and the uncertainty associated with this expectation. In light of this 
observation, it appears that bank loans, foreign and state finance have positive ramifications on entry size by reducing the firms' uncertainty regarding the future.

In an influential paper, Rajan and Zingales (1998) advanced the idea that different industrial sectors are likely to face different external financing requirements due to their technological differences, and for this reason the impact of financial development is likely to be different across different sectors. We explore the extent to which this idea applies in the context of the effect of finance on start-up size in China by re-estimating our model on each of the four sub-samples defined by the industries' level of technology intensity ${ }^{4}$. Tables 4-7 report the results from this experiment. In general, our conclusion that formal financing channels have positive effects on entry size, while firms that rely disproportionately on informal finance enter the market with a relatively small size, holds across all sectors. There are, however, some noteworthy industry heterogeneities. Firstly, the impact of bank loans is most pronounced amongst high-tech industry firms at the upper end of the size distribution (Table 7). Secondly, state finance has uniformly positive effects in low-medium technology industries only (Table 5). Finally, informal financing channels do not appear to have any impact on the start-up size of the majority of firms entering in high-tech industries (Table 7).

\section{Conclusions}

Using a unique dataset that provides information on the financial structure of startup companies in the Chinese manufacturing industries, this paper documents robust evidence that access to formal financing channels has beneficial effects on firm size, these effects being more marked as we move up the entry size distribution. By contrast, we

\footnotetext{
${ }^{4}$ See Appendix A for details on the classification of technology intensity.
} 
find negative relationships between informal finance and entry size across all size quantiles. Given the well-documented positive correlations between firm size and numerous performance indicators (e.g. productivity, exporting and survival), this paper has therefore uncovered entry size as an additional channel through which financial development promotes growth. The finding has relevance to the vibrant literature on finance and growth, especially to the strand of the literature that seeks to document the distributional effects of financial development.

Our work has also an important policy implication. Given the correlation between firm size and performance, the extent to which Chinese start-up companies will create longer lasting jobs as well as significantly contribute to aggregate productivity growth is directly related to their access to the state-dominated banking system. In this sense, our paper has highlighted the potential benefits of more tightly coordinating the on-going reforms of the Chinese financial system with existing industrial development strategies. 


\section{References:}

Allen, Franklin, Qian, Jun and Qian, Meijun, 2005, Law, Finance, and Economic Growth in China, Journal of Financial Economics 77, 57-116.

Arnott, Richard, and Joseph E. Stiglitz, 1990, Moral Hazard and Nonmarket Institutions: Dysfunctional Crowing Out or Peer Monitoring, American Economic Review, 81:1, 179-90

Beck, Thorsten, Asli Demirgüc-Kunt, and Vojislav Maksimovic, 2005, Financial and Legal Constraints to Firm Growth: Does Firm Size Matter? Journal of Finance, 60, 137177

Beck, Thorsten, Asli Demirgüc-Kunt, Luc Laeven and Ross Levine, 2007, Finance, Firm Size, and Growth, World Bank

Beesley, M.E. and Hamilton, R.E. 1984, Small Firms' Seedbed Role and the Concept of Turbulence, Journal of Industrial Economics, 33, 217-231.

Cabral, L and J. Mata, 2003, On the evolution of the firm size distribution, American Economic Review, 93, 1075-90.

Caves, R.E., 1998, Industrial Organization and New Findings on Turnovers and Mobility of Firms, Journal of Economic Literature, 36, 4, 1947-82.

China Finance Society, Almanac of China's Finance and Banking (Annual, various issues), Beijing: China Financial Publishing House.

China Statistical Yearbook (various issues), National Bureau of Statistics of China.

Dollar, D., Hallward-Driemeier, M., Shi, A., Wallsten, S., Wang, S. and Xu, L. C., 2003, Improving the Investment Climate in China, Investment Climate Assessment, World Bank and International Finance Corporation.

Du, Jun, 2006, PhD Thesis: Essays on Banking Efficiency, Access to Finance and Firm Performance in China, University of Leicester

Du, J and Girma, S, 2007, Financing Source and Firm Growth in a Hybrid Financial System: Evidence from China, Research paper, available at http://papers.ssrn.com/sol3/papers.cfm?abstract_id=1032942.

Du, Jun and Girma, S, 2008, Source of Finance, Growth and Firm Size, research paper available at http://papers.ssrn.com/sol3/papers.cfm?abstract_id $=1306309$. 
Garcia-Fontes, Walter, 2005, Small and Medium Enterprises Financing in China, Central Bank of Malaysia Working Paper

Germidis, Dimitri, Kessler, Denis and Meghir, Rachel, 1991, Financial Systems and

Development: What Role for the Formal and Informal Financial Sectors? OECD.

Geroski, P., 1991, Market Dynamics and Entry, Oxford: Basil Blackwell

Geroski, P.A., 1995, What Do We Know About Entry? International Journal of Industrial Organization, 13, 421-440

Görg, H. and E. Strobl 2001, "Multinational companies and entrant start-up size: Evidence from quantile regressions”, Review of Industrial Organization, 20, 15-31.

Huang, Yashang, 2003, Selling China, Cambridge University Press.

Koenker, R. and Bassett, G. 1978, Regression Quantiles, Econometrica, 46, 33-50.

La Porta, R., Lopez-de-Silanes, F., Shleifer, A., Vishny, R., 1998, Law and finance, Journal of Political Economy, 106, 1113-1155.

Levine, Ross, 2005, 'Finance and growth: Theory and evidence', Handbook of Economic Growth.

Lin, Justin Yifu, Fang, Cai and Zhou, Li, 1998. Competition, policy burdens, and stateowned enterprise reform. American Economic Review 88 2, pp. 422-427

Lin, Justin Yifu and Liu, Zhiqiang, Fiscal Decentralization and Economic Growth in China, 2000, Economic Development and Cultural Change, Vol. 49, No. 1, pp. 1-21

Maksimovic, Volislav Demirgüç-Kunt, Asli and Ayyagari, Meghana, 2008, Formal versus Informal Finance: Evidence from China, World Bank Policy Research Working Paper No. 4465. Available at SSRN: http://ssrn.com/abstract $=1080690$

Mata, J. and Machado, J.A.E. 1996, "Firm start-up size: A conditional quantile approach", European Economic Review, 40, 1305-1323.

Mata, J., Portugal, P. and Guimaraes, P., 1995, The survival of new plants: Start-up conditions and post-entry evolution, International Journal of Industrial Organisation 13, 459-481.

Rajan, R. and Zingales, L. 1998, "Financial dependence and growth". American Economic Review 88, 559-586

Stiglitz, J. 1990. Peer Monitoring and Credit Markets, World Bank Economic Review, $4(3): 351-66$.

Sutton, J. 1991. Sunk Costs and Market Structure. Cambridge, MA: MIT Press. 
Figure 1: Histograms of start-up size for 2000 and 2005
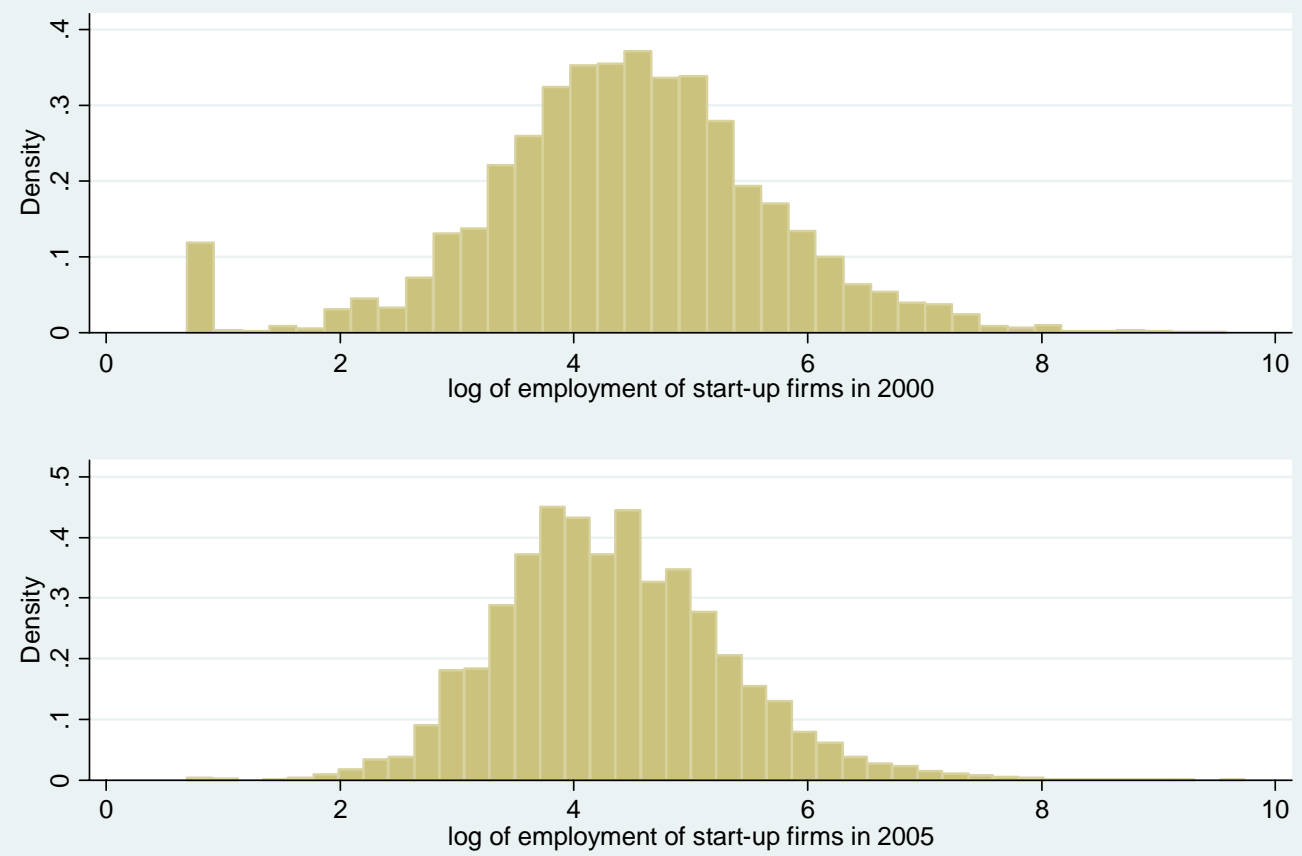

Figure 2:

Start-up size effects of bank loans (Fig. 2a) and self-raised finance (Fig. 2b):

Point estimates and $95 \%$ confidence intervals across all quantiles
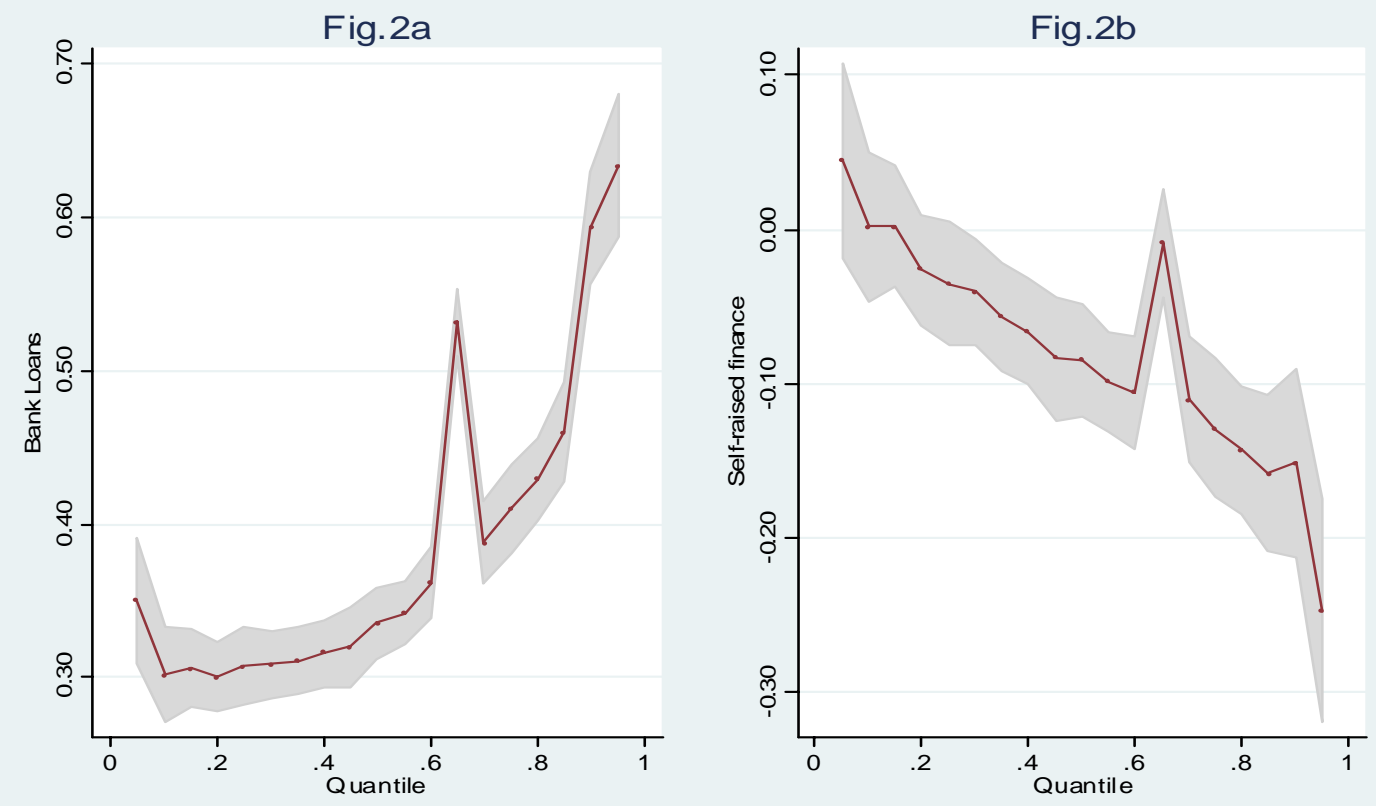


\section{Table 1}

Frequency distribution of start-ups by year and technology intensity of industry

\begin{tabular}{|c|r|r|r|r|r|}
\hline & \multicolumn{4}{|c|}{ Technology intensity } & High \\
\hline $\begin{array}{l}\text { Entry } \\
\text { year }\end{array}$ & $\begin{array}{l}\text { Ledium- } \\
\text { low }\end{array}$ & $\begin{array}{r}\text { Medium- } \\
\text { high }\end{array}$ & & \\
\hline 2000 & 1,878 & 1,869 & 669 & 449 & 4,865 \\
\hline 2001 & 4,070 & 3,642 & 1,777 & 944 & 10,433 \\
\hline 2002 & 3,707 & 3,174 & 1,595 & 859 & 9,335 \\
\hline 2003 & 5,513 & 5,152 & 2,263 & 1,102 & 14,030 \\
\hline 2004 & 13,134 & 12,639 & 6,663 & 3,206 & 35,642 \\
\hline 2005 & 6,537 & 6,142 & 3,033 & 1,561 & 17,273 \\
\hline Total & 34,839 & 32,618 & 16,000 & 8,121 & 91,578 \\
\hline
\end{tabular}

Note: The classification of technology intensity is given in Appendix A.

Table 2

Summary statistics

\begin{tabular}{|l|l|l|r|}
\hline Variable & Definition & Mean & $\begin{array}{r}\text { Standard } \\
\text { deviation }\end{array}$ \\
\hline Entry size & Log of employment & 4.413 & 1.006 \\
\hline Bank loans & $\begin{array}{l}\text { Bank loans at time of start-up } \\
\text { divided by total asset }\end{array}$ & 0.112 & 0.314 \\
\hline Foreign finance & $\begin{array}{l}\text { The share of foreign finance in } \\
\text { start-up firm's equity }\end{array}$ & 0.144 & 0.330 \\
\hline State finance & $\begin{array}{l}\text { The share of state finance in start- } \\
\text { up firm's equity }\end{array}$ & 0.024 & 0.142 \\
\hline Self-raised finance & $\begin{array}{l}\text { Self-raised finance at time of start- } \\
\text { up divided by total asset. }\end{array}$ & 0.782 & 0.389 \\
\hline Minimum efficiency scale & $\begin{array}{l}\text { Log of industry median } \\
\text { employment }\end{array}$ & 4.700 & 0.365 \\
\hline Turbulence & Sum of industry entry and exit rates & 0.204 & 0.060 \\
\hline Industry growth & Industry sales growth & 0.090 & 0.367 \\
\hline FDI & $\begin{array}{l}\text { Share foreign multinationals in sales } \\
\text { in total industry sales }\end{array}$ & 0.001 & 0.007 \\
\hline Herfindhal & $\begin{array}{l}\text { Herfindhal measure of industry } \\
\text { concentration calculated in terms of } \\
\text { market shares. }\end{array}$ & 0.083 & 0.114 \\
\hline Observations & 91578 & & \\
\hline
\end{tabular}


Table 3:

Finance and start-up size in China:

Quantile regression estimates

\begin{tabular}{|c|c|c|c|c|c|}
\hline & \multicolumn{5}{|c|}{ Quantiles } \\
\hline & $10^{\text {th }}$ & $25^{\text {th }}$ & $50^{\text {th }}$ & $75^{\text {th }}$ & $90^{\text {th }}$ \\
\hline \multirow[t]{2}{*}{ Bank loans } & $0.347 * * *$ & $0.302 * * *$ & $0.307 * * *$ & $0.335 * * *$ & $0.410 * * *$ \\
\hline & $(0.010)$ & $(0.016)$ & $(0.013)$ & $(0.012)$ & $(0.015)$ \\
\hline \multirow[t]{2}{*}{ Foreign finance } & $0.318 * * *$ & $0.228 * * *$ & $0.282^{* * * *}$ & $0.330 * * *$ & $0.367 * * *$ \\
\hline & $(0.017)$ & $(0.028)$ & $(0.023)$ & $(0.021)$ & $(0.026)$ \\
\hline \multirow[t]{2}{*}{ State finance } & $0.477 * * * *$ & $-1.685 \% * * *$ & $0.291 \% * \%$ & $0.495 * * *$ & $0.710 * * *$ \\
\hline & $(0.026)$ & $(0.028)$ & $(0.035)$ & $(0.032)$ & $(0.039)$ \\
\hline \multirow[t]{2}{*}{ Informal finance } & $-0.086 * * *$ & 0.001 & -0.035 & $-0.085^{* * *}$ & $-0.129 * * *$ \\
\hline & $(0.015)$ & $(0.025)$ & $(0.020)$ & $(0.019)$ & $(0.023)$ \\
\hline \multirow[t]{2}{*}{ Minimum efficient scale } & $0.808 * * *$ & $0.660 * * *$ & $0.746 * * *$ & $0.826 * * *$ & $0.858 * * *$ \\
\hline & $(0.009)$ & $(0.014)$ & $(0.011)$ & $(0.011)$ & $(0.013)$ \\
\hline \multirow[t]{2}{*}{ Turbulence } & $0.123 *$ & -0.019 & 0.057 & $0.142 *$ & $0.164 *$ \\
\hline & $(0.052)$ & $(0.083)$ & $(0.069)$ & $(0.065)$ & $(0.079)$ \\
\hline \multirow[t]{2}{*}{ Industry growth } & $0.032 * * *$ & $0.033 *$ & $0.034 \% *$ & $0.033 \% *$ & $0.035 * *$ \\
\hline & $(0.008)$ & $(0.015)$ & $(0.012)$ & $(0.010)$ & $(0.012)$ \\
\hline \multirow[t]{2}{*}{ FDI } & $-3.033^{* * * *}$ & $-10.405 \% * \%$ & $-6.184 * * *$ & $-2.277 * * *$ & -1.465 \\
\hline & $(0.420)$ & $(0.438)$ & $(0.431)$ & $(0.513)$ & $(0.799)$ \\
\hline \multirow[t]{2}{*}{ Herfindhal index } & 0.051 & $-0.211 * * *$ & $-0.161 * * *$ & 0.044 & $0.291 * * *$ \\
\hline & $(0.027)$ & $(0.042)$ & $(0.036)$ & $(0.033)$ & $(0.040)$ \\
\hline Observations & 91578 & 91578 & 91578 & 91578 & 91578 \\
\hline
\end{tabular}

Notes:

a. Asymptotic standard errors are given in parentheses

b. significant at $10 \%$; ** significant at $5 \%$; *** significant at $1 \%$

c. All specifications include time dummies. 
Table 4:

Finance and start-up size in low-technology industries

\begin{tabular}{|c|c|c|c|c|c|}
\hline & \multicolumn{5}{|c|}{ Quantiles } \\
\hline & $10^{\text {th }}$ & $25^{\text {th }}$ & $50^{\text {th }}$ & $75^{\text {th }}$ & $90^{\text {th }}$ \\
\hline \multirow[t]{2}{*}{ Bank loans } & $0.340 * * *$ & $0.322 * * *$ & $0.326 * * *$ & $0.404 * * *$ & $0.526 * * *$ \\
\hline & $(0.025)$ & $(0.017)$ & $(0.019)$ & $(0.020)$ & $(0.031)$ \\
\hline \multirow[t]{2}{*}{ Foreign finance } & $0.328 \% * \%$ & $0.415^{* * * *}$ & $0.381 * * * *$ & $0.376 * * * *$ & $0.269 * * * *$ \\
\hline & $(0.046)$ & $(0.032)$ & $(0.035)$ & $(0.036)$ & $(0.056)$ \\
\hline \multirow[t]{2}{*}{ State finance } & $-0.151 \%$ & $0.163 * * *$ & $0.301 * * *$ & $0.468 * * *$ & $0.550 * * *$ \\
\hline & $(0.069)$ & $(0.048)$ & $(0.052)$ & $(0.052)$ & $(0.082)$ \\
\hline \multirow[t]{2}{*}{ Informal finance } & -0.064 & -0.029 & $-0.123 * * *$ & $-0.153 * * *$ & $-0.244 * * *$ \\
\hline & $(0.041)$ & $(0.029)$ & $(0.032)$ & $(0.033)$ & $(0.051)$ \\
\hline \multirow{2}{*}{$\begin{array}{l}\text { Minimum } \\
\text { efficient scale }\end{array}$} & $0.724 * \% *$ & $0.788 \% * \%$ & $0.845 * * * *$ & $0.861 * * *$ & $0.881 \% * \%$ \\
\hline & $(0.022)$ & $(0.015)$ & $(0.017)$ & $(0.018)$ & $(0.028)$ \\
\hline \multirow[t]{2}{*}{ Turbulence } & $0.478 *$ & 0.223 & 0.180 & 0.290 & $0.723 \%$ \\
\hline & $(0.210)$ & $(0.145)$ & $(0.159)$ & $(0.162)$ & $(0.247)$ \\
\hline \multirow[t]{2}{*}{ Industry growth } & $0.100 * * *$ & $0.111 * * *$ & $0.103 * * *$ & $0.085^{* * *}$ & $0.150 * * *$ \\
\hline & $(0.029)$ & $(0.020)$ & $(0.022)$ & $(0.023)$ & $(0.039)$ \\
\hline \multirow[t]{2}{*}{ FDI } & -5.324 & $-7.293 \% *$ & -2.032 & $-6.614 \%$ & -5.160 \\
\hline & $(4.072)$ & $(2.769)$ & $(2.968)$ & $(3.150)$ & $(5.093)$ \\
\hline \multirow[t]{2}{*}{ Herfindhal index } & 0.040 & $0.205^{* * *}$ & $0.377 * * *$ & $0.708 * * *$ & $1.049 * * *$ \\
\hline & $(0.096)$ & $(0.063)$ & $(0.068)$ & $(0.066)$ & $(0.097)$ \\
\hline Observations & 34839 & 34839 & 34839 & 34839 & 34839 \\
\hline
\end{tabular}

Notes:

d. Asymptotic standard errors are given in parentheses

e. significant at $10 \%$; ** significant at $5 \%$; *** significant at $1 \%$

f. All specifications include time dummies. 
Table 5:

Finance and start-up size in low-medium technology industries

\begin{tabular}{|c|c|c|c|c|c|}
\hline & \multicolumn{5}{|c|}{ Quantiles } \\
\hline & $10^{\text {th }}$ & $25^{\text {th }}$ & $50^{\text {th }}$ & $75^{\text {th }}$ & $90^{\text {th }}$ \\
\hline \multirow[t]{2}{*}{ Bank loans } & $0.231 \% * \%$ & $0.275 * * *$ & $0.318 * * *$ & $0.379 * * *$ & $0.490 * * *$ \\
\hline & $(0.022)$ & $(0.021)$ & $(0.017)$ & $(0.021)$ & $(0.028)$ \\
\hline \multirow[t]{2}{*}{ Foreign finance } & $0.172 * * *$ & $0.162 * * *$ & $0.193 * * *$ & $0.320 * * *$ & $0.347 * * * *$ \\
\hline & $(0.041)$ & $(0.038)$ & $(0.031)$ & $(0.039)$ & $(0.051)$ \\
\hline \multirow[t]{2}{*}{ State finance } & $0.391 \% * *$ & $0.407 * * *$ & $0.573^{* * * *}$ & $0.787 * * * *$ & $0.931 * * *$ \\
\hline & $(0.061)$ & $(0.057)$ & $(0.046)$ & $(0.057)$ & $(0.075)$ \\
\hline \multirow[t]{2}{*}{ Informal finance } & 0.022 & -0.054 & $-0.098 * * *$ & $-0.127 * * *$ & $-0.201 * * *$ \\
\hline & $(0.033)$ & $(0.032)$ & $(0.025)$ & $(0.032)$ & $(0.043)$ \\
\hline \multirow{2}{*}{$\begin{array}{l}\text { Minimum } \\
\text { efficient scale }\end{array}$} & $0.738 \% * *$ & $0.840 * * *$ & $0.914 * * * *$ & $0.965 * * *$ & $0.894 * * *$ \\
\hline & $(0.021)$ & $(0.020)$ & $(0.016)$ & $(0.020)$ & $(0.027)$ \\
\hline \multirow[t]{2}{*}{ Turbulence } & $0.683 * * *$ & $0.896 * * *$ & $1.424 * * *$ & $1.891 \% * \%$ & $2.046 * * *$ \\
\hline & $(0.195)$ & $(0.190)$ & $(0.154)$ & $(0.196)$ & $(0.255)$ \\
\hline \multirow[t]{2}{*}{ Industry growth } & $0.067 * * *$ & $0.052^{* * *}$ & $0.051 * * *$ & $0.082 * * *$ & $0.105 * * *$ \\
\hline & $(0.018)$ & $(0.019)$ & $(0.015)$ & $(0.019)$ & $(0.026)$ \\
\hline \multirow[t]{2}{*}{ FDI } & $-6.231 \% * *$ & $-3.714 * * *$ & $-1.917 * * *$ & -1.039 & -0.726 \\
\hline & $(0.392)$ & $(0.458)$ & $(0.455)$ & $(0.715)$ & $(0.828)$ \\
\hline \multirow[t]{2}{*}{ Herfindhal index } & $-0.274 \% * *$ & $-0.224 * * *$ & -0.012 & $0.262 * * *$ & $0.618 * * *$ \\
\hline & $(0.055)$ & $(0.054)$ & $(0.043)$ & $(0.054)$ & $(0.068)$ \\
\hline Observations & 32618 & 32618 & 32618 & 32618 & 32618 \\
\hline
\end{tabular}

Notes:
a. Asymptotic standard errors are given in parentheses
b. significant at $10 \%$; ** significant at $5 \%$; *** significant at $1 \%$
c. All specifications include time dummies. 
Table 6:

Finance and start-up size in medium-high technology industries

\begin{tabular}{|c|c|c|c|c|c|}
\hline & \multicolumn{5}{|c|}{ Quantiles } \\
\hline & $10^{\text {th }}$ & $25^{\text {th }}$ & $50^{\text {th }}$ & $75^{\text {th }}$ & $90^{\text {th }}$ \\
\hline \multirow[t]{2}{*}{ Bank loans } & $0.296 * * *$ & $0.217 * * * *$ & $0.089 * *$ & $0.436 * * * *$ & $0.583 * * *$ \\
\hline & $(0.037)$ & $(0.021)$ & $(0.032)$ & $(0.037)$ & $(0.051)$ \\
\hline \multirow[t]{2}{*}{ Foreign finance } & $0.181 \% *$ & $1.095 * * *$ & -0.067 & $0.371 * * *$ & $0.500 * * *$ \\
\hline & $(0.061)$ & $(0.028)$ & $(0.053)$ & $(0.059)$ & $(0.082)$ \\
\hline \multirow[t]{2}{*}{ State finance } & -0.073 & $1.250 * * *$ & $0.704 * * *$ & $0.923 * * *$ & $1.161 \% * \%$ \\
\hline & $(0.100)$ & $(0.053)$ & $(0.085)$ & $(0.095)$ & $(0.126)$ \\
\hline \multirow[t]{2}{*}{ Informal finance } & -0.007 & $0.898 \% * *$ & $0.513 * * * *$ & $-0.121 *$ & -0.098 \\
\hline & $(0.055)$ & $(0.023)$ & $(0.047)$ & $(0.053)$ & $(0.074)$ \\
\hline \multirow{2}{*}{$\begin{array}{l}\text { Minimum efficient } \\
\text { scale }\end{array}$} & $0.478 * \% *$ & $0.545 \% * *$ & $0.270 \% * \%$ & $0.983 * \% *$ & $0.915 \% * *$ \\
\hline & $(0.062)$ & $(0.035)$ & $(0.051)$ & $(0.058)$ & $(0.079)$ \\
\hline \multirow[t]{2}{*}{ Turbulence } & $1.473 * *$ & $2.345 * * *$ & $-4.171 * * *$ & $2.514 * * *$ & $2.269 * * *$ \\
\hline & $(0.459)$ & $(0.255)$ & $(0.366)$ & $(0.415)$ & $(0.575)$ \\
\hline \multirow[t]{2}{*}{ Industry growth } & 0.002 & -0.041 & $0.081 *$ & 0.054 & 0.016 \\
\hline & $(0.046)$ & $(0.025)$ & $(0.035)$ & $(0.038)$ & $(0.053)$ \\
\hline \multirow[t]{2}{*}{ FDI } & $20.346 * * *$ & $10.104 * * *$ & $\begin{array}{l}- \\
19.581 \% * \%\end{array}$ & $-4.844^{*}$ & $-6.672 *$ \\
\hline & $(2.070)$ & $(1.341)$ & $(2.028)$ & $(2.323)$ & $(3.008)$ \\
\hline \multirow[t]{2}{*}{ Herfindhal index } & 0.119 & 0.064 & $-0.332 * * *$ & $0.386 * * * *$ & $0.565 \% * *$ \\
\hline & $(0.093)$ & $(0.056)$ & $(0.086)$ & $(0.098)$ & $(0.130)$ \\
\hline Observations & 16000 & 16000 & 16000 & 16000 & 16000 \\
\hline
\end{tabular}

\section{Notes:}
a. Asymptotic standard errors are given in parentheses
b. significant at $10 \%$; ** significant at $5 \%$; *** significant at $1 \%$
c. All specifications include time dummies. 
Table 7:

Finance and start-up size in high -technology industries

\begin{tabular}{|c|c|c|c|c|c|}
\hline & \multicolumn{5}{|c|}{ Quantiles } \\
\hline & $10^{\text {th }}$ & $25^{\text {th }}$ & $50^{\text {th }}$ & $75^{\text {th }}$ & $90^{\text {th }}$ \\
\hline \multirow[t]{2}{*}{ Bank loans } & $0.415 * * *$ & $0.419 * * *$ & $0.413 * * *$ & $0.487 * * *$ & $0.626 * * *$ \\
\hline & $(0.056)$ & $(0.037)$ & $(0.039)$ & $(0.044)$ & $(0.081)$ \\
\hline \multirow[t]{2}{*}{ Foreign finance } & $0.274 * *$ & $0.324 * * *$ & $0.458 * * *$ & $0.517 * * * *$ & $0.599 * * *$ \\
\hline & $(0.096)$ & $(0.067)$ & $(0.067)$ & $(0.077)$ & $(0.128)$ \\
\hline \multirow[t]{2}{*}{ State finance } & -0.112 & $0.207 *$ & $0.333^{* * * *}$ & $0.688 * * * 6$ & $-1.411 \% * *$ \\
\hline & $(0.140)$ & $(0.094)$ & $(0.097)$ & $(0.111)$ & $(0.332)$ \\
\hline \multirow[t]{2}{*}{ Informal finance } & 0.066 & -0.040 & -0.101 & $-0.151^{*}$ & $-0.264 *$ \\
\hline & $(0.091)$ & $(0.063)$ & $(0.063)$ & $(0.073)$ & $(0.122)$ \\
\hline \multirow{2}{*}{$\begin{array}{l}\text { Minimum efficient } \\
\text { scale }\end{array}$} & $0.652 * * * *$ & $0.614 * * * *$ & $0.758 \% * \%$ & $0.923 * * *$ & $1.014 * * *$ \\
\hline & $(0.077)$ & $(0.051)$ & $(0.052)$ & $(0.059)$ & $(0.105)$ \\
\hline \multirow[t]{2}{*}{ Turbulence } & 0.936 & 0.581 & 0.509 & $1.210 * *$ & 1.213 \\
\hline & $(0.534)$ & $(0.370)$ & $(0.394)$ & $(0.459)$ & $(0.818)$ \\
\hline \multirow[t]{2}{*}{ Industry growth } & 0.012 & 0.010 & 0.012 & -0.021 & -0.066 \\
\hline & $(0.024)$ & $(0.018)$ & $(0.019)$ & $(0.021)$ & $(0.034)$ \\
\hline \multirow[t]{2}{*}{ FDI } & -2.370 & -1.604 & 3.544 & $14.733 * * *$ & 0.518 \\
\hline & $(2.101)$ & $(1.956)$ & $(2.389)$ & $(2.139)$ & $(4.699)$ \\
\hline \multirow[t]{2}{*}{ Herfindhal index } & $-0.313 * *$ & -0.158 & 0.034 & $0.284 *$ & $0.520 * \%$ \\
\hline & $(0.120)$ & $(0.088)$ & $(0.096)$ & $(0.111)$ & $(0.200)$ \\
\hline Observations & 8121 & 8121 & 8121 & 8121 & 8121 \\
\hline
\end{tabular}

Notes:
a. Asymptotic standard errors are given in parentheses
b. significant at $10 \%$; ** significant at $5 \%$; *** significant at $1 \%$
c. All specifications include time dummies. 


\section{Appendix A:}

\section{Classification of manufacturing industries by level of technology intensity.}

\begin{tabular}{|c|c|}
\hline Level of technology intensity & NACE two digits code (Divisions) \\
\hline High-technology sectors & $\begin{array}{l}\text { Manufacture of office machinery and computers } \\
\text { (30); Manufacture of radio, television and } \\
\text { communication equipment and apparatus(32); } \\
\text { Manufacture of medical, precision and optical } \\
\text { instruments, watches and clocks (33). }\end{array}$ \\
\hline Medium-high technology sectors & $\begin{array}{l}\text { Manufacture of electrical machinery and apparatus } \\
\text { n.e.c. (31); Manufacture of motor vehicles, trailers } \\
\text { and semi-trailers (34); Manufacture of chemicals } \\
\text { and chemical products (24); Manufacture of } \\
\text { machinery and equipment n.e.c. (29); Manufacture } \\
\text { of other transport equipment (35) }\end{array}$ \\
\hline Medium-low technology sectors & $\begin{array}{l}\text { Manufacture of coke, refined petroleum products } \\
\text { and nuclear fuel (23); Manufacture of rubber and } \\
\text { plastic products (25); Manufacture of other non- } \\
\text { metallic mineral products (26); Manufacture of } \\
\text { basic metals (27); Manufacture of fabricated metal } \\
\text { products, except machinery and equipment (28) }\end{array}$ \\
\hline Low technology sectors & $\begin{array}{l}\text { Manufacture of food products and beverages (15); } \\
\text { Manufacture of tobacco products (16); Manufacture } \\
\text { of textiles (17); Manufacture of wearing apparel; } \\
\text { dressing and dyeing of fur (18); Tanning and } \\
\text { dressing of leather; manufacture of luggage, } \\
\text { handbags, harness and footwear (19); } \\
\text { Manufacture of wood and of products of wood and } \\
\text { cork, except furniture; manufacture of articles of } \\
\text { straw and plaiting materials (20); Manufacture of } \\
\text { pulp, paper and paper products (21); Publishing, } \\
\text { printing and reproduction of recorded media (22); } \\
\text { Manufacture of furniture; manufacturing n.e.c. (36) }\end{array}$ \\
\hline
\end{tabular}

Source: Eurostat-OECD classification of technology-intensive sectors. 